УДК 784.4(497.7)(091)

https://doi.org/10.55302/MF2180037k

Александра Кузман

\title{
МАКЕДОНСКАТА ЧАЛГИЈА НИЗ ИСТРАЖУВАЊАТА, ПЕСНИТЕ, ПРИКАЗНИТЕ И ДОКУМЕНТАРНИТЕ ЕМИСИИ
}

\begin{abstract}
Апстракт: Македонската чалгија, како специфичен музички жанр на вокалноинструментално музицирање, била значајна градска музичка традиција што вешто била вплетена во секојдневието на градскиот човек. Таа најизразено била присутна во XIX и во XX век, и иако со текот на времето постепено замрела како традиција, сепак оставила извесни траги низ историските документи и архиви. Посебно се значајни материјалите од собирачот на македонски народни умотворби - Марко Цепенков, каде што низ описи, но и низ народните приказни, се спомнува за постоењето на чалгијата и на чалгиските музички инструменти во некогашното македонско музичко минато. Постоењето на чалгијата е засведочено и во песните создадени во поново време, но и во малиот број постојни документи и аудиоматеријали што ги поседуваат градските архиви. Не треба да се прескокнат ниту бројните документарни емисии посветени на македонската староградска музика, вклучително и на чалгиската, коишто се достапни на интернет-сервисот „YouTube“. Овие аудио-/видеосодржини се во продукција на Македонската радио-телевизија, кои се снимиле како резултат на трендот на навраќање и на афирмација на староградската песна.

Клучни зборови: македонска чалгија, истражувачи, документираност, аудио/видеоматеријали.
\end{abstract}

Македонската чалгија, како специфичен музички жанр на вокалноинструментално музицирање, била дел од македонското градско секојдневие најмногу во XIX и во XX век, но по нејзиното стишување како градска музичка традиција, сепак не го оставила рамнодушно истражувачкото уво на македонските етномузиколози. Во потрагата по нејзиното постоење се впуштиле неколкумина истражувачи, пред сѐ, некогашни вработени во Институтот за фолклор „Марко Цепенков“ во Скопје. За тие истражувања денес зборува богатиот архивски фонд во истоимениот Институт ${ }^{1}$, кој грижливо ги чува тие податоци за некогашната присутност на чалгиската традиција на овие простори, која некако успева да преживее до денес, но веќе со извесни промени во одредени аспекти од нејзиното постоење.

Еден од најзаслужните истражувачи, кој потемелно ја истражувал чалгиската музичка традиција и којшто придонел за збогатување на спомнатиот архивски фонд со материјали поврзани со оваа тема, а потоа

\footnotetext{
${ }^{1}$ Архивските материјали и документи поврзани со македонската чалгиска традиција што се наоѓаат и се во сопственост на Институтот за фолклор „Марко Цепенков“ Скопје, како и во другите градски архиви што беа посетени за да се направи увид во постојната документација што ја засега оваа тема, ќе бидат презентирани во вториот дел од трудов што ќе се објави во бр. 81 од Макеgонски фолклор.
} 
објавил и два значајни труда поврзани со истата тематика, на таков начин поставувајќи ги основите за тоа што претставува чалгијата, е етномузикологот Боривоје Џимревски.

Пред сѐ, треба да се спомне неговиот опсежен труд под наслов „Чалгиската традиција во Македонија“ (Џимревски 1985a), а потоа и другиот негов труд „Градска инструментална музичка традиција во Македонија [1900 - 1941]“" (Џимревски 2005), каде што повторно станува збор за чалгиската музика, но се опфатени и другите видови староградска музика. Покрај овие негови поголеми трудови, тој е автор и на повеќе текстови ${ }^{2}$ поврзани со истата или со слична тематика објавени во некои зборници на трудови, како и во списанието Макеоонски фолклор, кое го издава Институтот за фолклор „Марко Цепенков“ - Скопје. ${ }^{3}$ Списанието Макеgонски фолклор е богато со најразлични фолклористички содржини, што е вистински значајно меѓу македонските истражувачки кругови, но и за пошироката македонска јавност, која ги разбира и ги почитува културните традиционални вредности. Всушност, ова списание изобилува со текстови од најразлични истражувачи од неколку различни истражувачки области и претставува одлична можност да се презентираат резултатите од направените анализи произлезени од нивните извршени теренски истражувања.

Треба да се спомнат и некои други истражувачи, кои делумно ја допираат темата за чалгијата, но од различни аспекти. Од областа на етноорганологијата треба да се истакнат истражувањата на Александар Линин (1986), каде што се содржани описи за чалгиските инструменти. Потоа, тука треба да се спомнат истражувањата на Ленка Татаровска, која пишува за староградската народна песна како дел од граѓанската поезија (2001), како и истражувањата на Илија Хр. Алушевски, кој пишува за битолската чалгија (1980: 817-823). За охридските трубадури пишува Никола Бошале (2004), а за потеклото на некои од охридските народни песни и приказни пишува Димче Маленко (1989). Неколку велешки народни песни обработува Никифор Смилевски, кој, како и многу други истражувачи, на некој начин делумно ја допира темата за македонската чалгија (2014). Димитар Митевски пишувајќки за музичкиот живот во Штип, спомнува неколку штипски чалгиски тајфи (1995), а за чалгиската традиција во Берово пишува Тимко Чичаковски во неговиот магистерски труд одбранет во 2012 година. Постојат текстови, во кои се обработува истата тематика, во Билтенот произлезен од манифестацијата „Охридски староградски средби“, меѓу кои може да се

\footnotetext{
2 За да не се оптоварува трудот премногу, насловите на текстовите на Џимревски (истовремено и на другите истражувачи), што на некаков начин се поврзани со македонската чалгија, дури и тие каде што чалгијата се спомнува само како термин, со целосни податоци ќе бидат наведени како библиографски единици поместени во делот Литература.

${ }^{3}$ Во ова списание, свој текст, каде што се спомнува постоењето на чалгиските состави што биле многу популарни во македонските градови, има и истражувачот Васил Хаџиманов (видете во Литература).
} 
наведат текстовите на: Харалампие Поленаковиќ, кој зборува за градската песна од аспект на нејзините текстуални содржини што многу сликовито го доловуваат животот во XIX век во македонските градски средини; текстот на Димче Маленко; потоа текстот на Живко Фирфов во кој се наведуваат поглавните градови, каде што се негувала чалгијата како музичка традиција, потоа се опишуваат четирите различни чалгиски стилови на музицирање, се зборува за чалгискиот репертоар, а се спомнуваат и чалгаџиски имиња итн.

Исто така треба да се спомнат и истражувањата за македонската чалгија направени од странски етномузиколози, како на пример истражувањата на Соња Тамар Симан ${ }^{4}$ (Seeman 1990), чијшто магистерски труд е посветен токму на македонската чалгија, како и истражувањето на финскиот етномузиколог Ристо Пека Пенанен, во кое го разгледува прашањето за урбаната отоманска музика, каде што наведува дека македонската чалгиска музика е урбан производ во којшто се видливи влијанијата од отоманската музика (Pennanen 2004: 1-25). ${ }^{5}$ Сестрите Даница и Љубица Јанковиќ спомнуваат постоење на призренска чалгија, која ја опишуваат како народен оркестар составен од: деф, кларинет и виолина (Јанковић 1951 [VI]: 12). Тука треба да се спомнат и Тимоти Pajc (Rice 1982: 122-137), кој истражува еден дел од инструменталната музика во Македонија, и Дона Бјукенан, која пишува за развојот на професионализмот на бугарските народни оркестри, но и за музиката во Пиринска Македонија, каде што го спомнува влијанието на професионализмот во македонската градска музика (Buchanan 1995: 381-416).

Повеќето од овие истражувачи се повикале на веќепостојни податоци и сведоштва за чалгијата забележани низ историските документи и архиви, што претставуваат и доказ дека таа некогаш постоела и била широко негувана музичка традиција во македонските градски средини, особено во периодот на Преродбата.

Посебно значајни сведоштва за постоењето на чалгијата, како дел од македонската музичка градска култура, се материјалите од собирачот на македонските народни умотворби - Марко Цепенков, кои се сметаат, можеби, за најстари записи што го опфаќаат прашањето за чалгиската музика и што се издадени во десет книги од Институтот за фолклор (во 1980 година), во редакција на Кирил Пенушлиски, каде што се спомнуваат чалгијата и чалгиските музички инструменти.

Така, во десеттата книга од овој собирач на народно творештво, во делот насловен како „Свирци табуанци (свиркала и тумпала) или чалгаџиски алати и орудија“" се сместени описите на некои народни музички инструменти, меѓу кои се и описите на инструментите што се дел од чалгискиот

\footnotetext{
4 Покрај магистерската теза, Соња Тамар Симан има уште еден труд поврзан со чалгиската музика, а тоа е текстот „Macedonian Čalgija: A Musical Refashioning of National Identity“ објавен во списанието Ethnomusicology forum во 2012 година.

5 Постои и друг негов труд во којшто го критикува пристапот на истражувањата на Боривоје Џимревски (Pennanen 2008: 127-147).
} 
инструментариум, проследени со визуелна илустрација за секој од нив (Цепенков 1980в [Х]: 152-157). Под спомнатиот наслов се сместени описите за: тарабуката, дајрето, ќемането, лаутата и канонот, а описот за кларинетот стои под насловот „Некои стари музикални органи“. (Под овој наслов стојат и други описи на тарабуката и дајрето).

Покрај описите на чалгиските инструменти, за некогашната присутност на чалгијата во секојдневниот живот на луѓето сведочат и народните приказни што ги забележал истиот собирач и што се пренесуваат со генерации низ времето. Во нив, поимот чалгија најчесто се спомнува во контекст на свадбените веселби. Таа не е само случајно спомната како поим, туку била директно вклучена во процесот на иницијација. Всушност, свадбата како еден многу значаен животен момент кај човекот, која претставува еден вид иницијација, односно премин од еден во друг стадиум во животот на еден млад човек, или попрецизно кажано, премин од еден во друг статус од младост и незрелост кон зрелоста и мудроста во животот, секогаш била проследена со музика, а често била оплеменета токму со звуците на чалгијата.

Еден таков пример претставува приказната „Иш беџерен, јалли кујурук jep - Работа што врши, дебела опашка јади“6, каде што гускарот, со итрина (претставувајќ́ се дека е царски син преправен во гускар), успева да се ожени со ќерката на пашата, а за свадбата што ја направиле, во приказната се вели дека пашата „курдисал свадба да праит (за керката, А. К.), со сите редишта како што требало. Санким сјунет дујуми праел. Курдисал секакви чалгии, навикал ќчеци и ченгии, навикал од секаде пеливани и цел месец што праел свадба“" (Цепенков $1980 б$ [V]: 128).

Во истата оваа збирка приказни се наоѓa и приказната „Момчето што велеше: ако да бев имал три грошеи, ке можев да бидам царев зет“77, каде што исто така, служејќи се со итрина, сиромашното момче навистина станува царски зет земајќи ја ќерката на некој цар за жена, по што следело голема свадба. Се вели: „,... музиките царцки, тапани, сурли и турли бе турли чалгии беше излегле и 'и пречекале како царцки син и снаа“" (Цепенков $1980 б$ [V]: 136). Во оваа приказна се забележува дека зборот „чалгија“ се однесува на конкретен музички состав на инструменти, бидејќи се издвојува од музиката на з(с)урлите и тапаните.

Потоа сведоштво за постоењето на чалгијата се сретнува и во приказната „Полза од знаење, комар играње и свирење“8, каде што синот на

\footnotetext{
${ }^{6}$ Марко К. Цепенков. 1980б. „Иш беџерен, јалли кујурук јер - Работа што врши, дебела опашка јади“ (приказна број 300). Книга 5: Нарояни ириказни - реалистиччни ириказни. Ред. д-р Кирил Пенушлиски, 123-131.

${ }^{7}$ Марко К. Цепенков. 1980б. „Момчето што велеше: ако да бев имал три грошеи, ќе можев да бидам царев зет“" (приказна број 301). Книга 5: Нарояни ириказни реалистиични йриказни. Ред. д-р Кирил Пенушлиски, 131-137.

${ }^{8}$ Марко К. Цепенков. 1980б. „Полза од знаење, комар играње и свирење“ (приказна број 329). Книга 5: Нарояни ириказни - реалисииччни ириказни. Ред. д-р Кирил Пенушлиски, 212-219.
} 
богатиот трговец научил да свири на кемане. Во приказната се вели: „... ошол син му од богатио на панаир и наместо стока да бара да купуат, избарал едни чалгаџии што свиреа со ќеманиња. И се еклеисал при нив да се учи ќемане. Во малце време беше се научил да свири ќемане, илјада пати од мајсторите што го учеа - поарно, чунки имал голема дарба да учи чалгија и друзи науки“ (Цепенков 1980б [V]: 213). Дека станува збор за надарен чалгаџија на чиј мајсторлак сите се восхитувале, па дури и царот, може да се согледа во еден друг пасус од истава приказна, каде што се вели: „Седејќи едно утро во првата одаја син му од богатио на пенџера, го видел царот кај седи на пенџере и тој, да си пие нарѓуле. 'Ја чекај да посвирам едно мане со ќеманено - си рекол сам со себе - да ме чуе царо и да се почуди.’ Кога тргна прачката, брате мило, да свири, секој што чул, застанал да слуша и се забораил да си оди по работата. А пак царот балдисал од сладина на мането што свирел. Откоа заптисал свирењето син му од богатио, царо пратил да го викни при него да му посвири. До тогај царо не беше чул таквоо убао свирење. Утро, вечер, сѐ го викал да му свири. Толку го замилуал царо, што прв риџал до него го зел. Од ортома чоек пуштал, од што го милуал царот“ (Цепенков $1980 б$ [V]: 216).

Во приказната „Царицата што била тешка и видела сон: ако изеи една зелена слива, ќе роди; и царо што најде слива во градината од еден силен арап и му го такса син му на арапо од петнаесет години да си го земи“", каде што е застапен мотивот на чудното раѓање, повторно зборот „чалгија“ е спомнат како дел од веселбата направена за свадбата на синот од царот. Во приказната се вели: „... коа си го видоа татко му и мајка му оти живо му дојде, па и со невеста, неисказана радос сториле. Курдисале свадба повторо, удриле свирки и чалгии; поканиле гости, пријатели и се веселиле токмо три месеци време... “ (Цепенков 1980a [II]: 295).

Покрај приказните на Марко Цепенков што претставуваат едно богато културно наследство, се разбира постојат и други примери на приказни што се пренесуваат усно од умешни раскажувачи и чувари на нашето културно богатство. Еден таков пример на приказна, каде што е претставена итрината на јунакот, кој прави свадба со чалгии, е волшебната народна приказна „Самовилата и детето“, забележана на магнетофонската лента бр. 717, прераскажана од страна на познатиот раскажувач Димитри Стенкоски ${ }^{10}$ од охридското село Пештани. Во приказната се вели дека момчето успеало да ја надитри самовилата и да ја земе за своја жена, при што направиле свадба, каде

\footnotetext{
${ }^{9}$ Марко К. Цепенков. 1980а. „Царицата што била тешка и видела сон: ако изеи една зелена слива, ќ роди; и царо што најде слива во градината од еден силен арап и му го такса син му на арапо од петнаесет години да си го земи“ (приказна број 73). Книга 2: Нарояни ирриказни - ириказни за живойни/волшебни ириказни. Ред. д-р Кирил Пенушлиски, 279-295.

10 Димитри Стенкоски (раскажувач на приказни) во разговор со Живко Чинго на 07.06.1968 г. во с. Пештани [интервјуто е снимено на магнетофонска лента бр. 717, која е во сопственост на Архивата на Институтот за фолклор „Марко Цепенков“ Скопје].
} 
што свиреле чалгиите. Покрај приказната што ја раскажува Стенкоски, се претпоставува дека има и други приказни на магнетофонските ленти, каде што се спомнува чалгијата, но тоа останува за некои идни истражувања.

Како сведоштво за постоењето на чалгијата и на чалгаџиите, покрај народните приказни, можат да послужат и некои чалгиски песни, но и песни од поново време, а тука ќе бидат наведени само некои од нив. Такви се примерите на охридските песни „Чудила се мила мама кому да ме дават“11 и „Бог да бијат, Сандро, твоја мајка“, наведени кај Киселиновиќ. Во првата песна, во набројувањето за кого да се мажи момата, покрај другите, се спомнува и чалгаџијата во стиховите:

Да ме дават на чалгаџи,

Јас чалгаџи сакам:

Тој ће свирит јас ће играм,

he се погодиме.

(Киселиновић 1926: 99). ${ }^{12}$

Во еден текст од Душко Хр. Константинов, објавен во списанието Макеоонски фолклор, со наслов „Еврејско влијание врз една македонска песна“, се вели дека оваа песна потекнува од народното музичко творештво на Македонските Евреи и што, во спомнатиов негов текст, е пренесена (како што вели самиот автор) на јуяео-есйањол. Дадени се неколку варијанти на македонски јазик, а во една од нив се дадени стиховите:

Чудила се, мила мама,

Кому да ме даде!

Да ме даде за чалгија, ${ }^{13}$

Јас чалгија сакам.

Тој ќе свирит, јас ќе играм,

Ке се погодиме.

(Константинов 1969: 242).

\footnotetext{
11 За оваа песна постои звучен музички пример достапен на интернет-сервисот „YouTube“, во изведба на познатата охридска музичка група „Охридски трубадури“, предводена од виолинистот Стојан Златановски. Линкот, вклучително и линковите за сите следни песни, ќе бидат дадени во делот Сајтографија, поместен на крајот од трудот.

12 Стиховите од оваа песна проследена и со мелографски запис, се наоѓаат и во книгата „Народне игре“ (књига IV), објавена во 1948 година, од сестрите Љубица и Даница Јанковиќ (Љубица и Даница Јанковић), на страница 272.

13 Веројатно станува збор за грешка или некоја јазична недоследност при преведувањето, бидејќи зборот „чалгија“ се однесува на поимот музика. Но, најверојатно, би требало да стои „чалгаџија“ што се однесува на оној што свири чалгиска музика.
} 
Во втората песна „Бог да бијат, Сандро, твоја мајка“ за која досега не е пронајден звучен музички пример, ниту податок од кого е создадена песната ${ }^{14}$, се спомнува името Климе Курте, кој бил познат охридски чалгаџија:

Бог да бијат, Сандро, твоја мајка,

Твоја мајка, Сандро, ќира Деспина,

Шчо те даде, Сандро, у Куртета,

У Куртета, Сандро, за Климета.

Ти не беше, Сандро, за Климета,

Туку беше, Сандро, за Јончета,

За Јончета, Сандро, од Робета.

(Киселиновић 1926: 62).

Треба да се истакне дека во стиховите од охридските песни „Фанче ојде во Калишча“ и „Песната за Деспина“, се знае дека токму самиот чалгаџија, истовремено и создавачот на песната, го вградува своето име. Така на пример, во „Песната за Деспина“ се спомнува Караѓуле (станува збор за еден од првите охридски чалгаџии - Анѓеле Караѓуле) во стиховите:

Во сӓботата на вечер,

Околу три сатот

Свирит Карађуле.

(Киселиновић 1926: 85),

а во песната „Фанче ојде во Калишча“ во стиховите:

Тамо имат чалгаџии,

Тамо свирит Карађуле

Карађуле со се тајфа.

(Киселиновић 1926: 88).

Песна што ја наведуваат сестрите Љубица и Даница Јанковиќ, каде се спомнува чалгијата, е тетовско-скопската песна, каде што белата божа (госпоѓa) ја придружуваат чалгијата и ченгиите. Тоа е во стиховите (каде што се дадени и објаснувања за помалкупознатите зборови) оригинално пренесени како што се напишани во книгата:

Виде'те, виде', бел', божо, кога [када] идеше од бања,

Со дванаесе алајке [дружбенице], со тринаесе огарке [чуварке],

Четрнаесе шегрке, со петнаесе робинке,

Со шеснаесе ченгије [играчице], со девет чифте [пари ${ }^{15}$ ч чалгије [свирачи],

${ }^{14}$ Нема да биде чудно доколку и самиот чалгаџија (Климе Курте), кој се спомнува во песната, да биде и нејзиниот создавач, бидејќи е познато дека самите чалгаџии вешто ги вметнувале своите имиња во песните што ги создавале, за да остават свој траен печат и за да бидат запаметени. 
Чалгије свирке свиреја, ченгије ти се кршеја,

Пауни сенка ти држеја, до висок сарај те испратија.

(Јанковић 1951 [VI]: 30).

Интересен пример претставува и песната „Коце берберот, чалгаџијата“"16 во зборникот на Коста Црнушанов:

Коце, берберот, чалгаџијата,

Коце, Коце, берберот, чалгаџијата,

Коце не јади расолно месо,

Коце не јади блага јавнија,

Блага јавнија со црни сливи,

Туку ми јади гуска полнета,

Гуска полнета со суво грозје;

Ушче ми јади јагне печено,

Јагне печено, на шиш вртено.

За да ви свири мошне убаво,

Брзо згответе гуска полнета,

Гуска полнета со суво грозје,

Јагне печено на шиш вртено,

И полејте ји с' тиквешко вино

Та да видите шчо убо ќе ви пеит,

Та да видите оро за мерак.

(Църнушанов 1956: 242). ${ }^{17}$

Создадени се и песни од поново време во коишто се спомнува чалгијата, како што се: „Ако одам во Битола“, „Ај, засвирете ми чалгии“ и „Ех, да свири сега Садило“.

\section{Ако одам во Битола}

Ако одам во Битола, ќе си купам до три пајтона, јас во еден ќе седам, други чалгии ќе свират, трети товар мерак ќе носам. ${ }^{18}$

\footnotetext{
15 Во дообјаснувањето што го даваат, пишува „пари“, но во овој случај „со девет чифте чалгије“ би значело „со девет пара чалгии“, односно чалгаџии, а не „пари“. Веројатно станува збор за грешка при објаснувањето.

${ }^{16}$ Се знае дека Коце, берберот, бил чалгаџија во Прилеп. Тој всушност бил активен организатор на музичкиот живот во својот град во почетокот на XX век (Џимревски 2005: 241).

17 Звучен музички пример од оваа песна постои од познатиот вокален интерпретатор на македонски патриотски, љубовни и хумористични песни - Јонче Христовски (Видете линк во Сајтографија).
} 


\section{Ај, засвирете ми чалгии}

$\mathrm{Aj}$, засвирете ми чалгии, една песна мераклиска, да се сетам на младоста, да се врати в'срце младоста. ${ }^{19}$

\section{Еx, да свири сега Садило}

Ех, да свири сега Садило, пусто срце би се напило, сиот Охрид пак да слуша музика што лечи душа, ех, да свири Садило. ${ }^{20}$

Во набројувањето на документацијата и на сведоштвата за постоењето на македонската чалгија не треба да се прескокнат и бројните документарни емисии ${ }^{21}$, посветени на македонската староградска музика, вклучително и на чалгиската. На достапниот интернет-сервис „YouTube“, покрај бројните аудиоснимки со изведби (постари и понови) на чалгиски песни, се наоѓаат и поголем број аудио-/видеосодржини, од кои дел се во продукција на Македонската радио-телевизија што се снимиле како резултат на трендот на навраќање и на афирмација на староградската песна. Значајна за оваа тема е документарната серија со наслов „Распеани градови“ што ја презентира македонската староградска песна од различни градови низ земјата, снимена во периодот од 1973 до 1975 година. Оваа серија е произлезена од проект на PTC/MTВ/МРТ (односно Телевизија Скопје) и содржи 21 емисија, каде што, како уредник, се јавува Петре М. Андреевски, сценарио и музички соработник е Јонче Христовски, а е во режија на Благоја Андреев (Видете во Сајтографија, даден е линк што ги содржи видеата од серијалот).

Во 2017 година е направена и документарна емисија посветена на охридската чалгиска музика со наслов „Садило, тајфите и чалгијата“ во продукција на телевизија „Сител“, каде што продуцент и организатор е Марјан Кировски, а во режија на Ристо Самарџиев и Дејан Таневски. Тука е и

\footnotetext{
18 Оваа песна била испеана на македонскиот музички фестивал „Валандово“ во 1989 година, во изведба на „Октет Македонија“. Музиката и текстот се од Петар ГеоргиевКалица, а аранжманот од Ѓорѓ Димчевски.

19 Авторот на оваа песна е претходноспомнатиот вокален интерпретатор на македонски песни - Јонче Христовски.

20 Оваа новокомпонирана песна била испеана на македонскиот музички фестивал „Охридски трубадури“ во 1996 година, во изведба на музичката група „Биоритам“.

21 За некои од документарните емисии достапни на интернет-сервисот „YouTube“, нема доволно податоци во чија продукција се снимени, бидејќи поголемиот број од нив се само исечоци, односно фрагментарни делови од целата документарна емисија (за дел од нив се дадени линкови во делот Сајтографија).
} 
документарниот филм „Кеиф“ во продукција на Award Film \& Video, во којшто како продуценти се јавуваат Владимир Стојчевски и Горан Стојилковик; режисер и монтажер - Блаже Дулев; сценарио - Ристо Солунчев; кинематографер - Горан Наумовски; дизајнер на звук - Дарко Спасовски Пацки, а официјално е презентиран пред јавноста во 2019 година. Преку интервјуа со македонски музичари, но и со светски познати уметници, како што се: Кудси Ерѓунер, Омар Фарук Текбилек, Ѓунај Челик, Симон Шахин и други, во спомнатиот документарен филм се прави обид да се проследи развојот, односно историјата и почетоците на чалгијата во Македонија.

Сите наведени документи, записи, аудио-/видеоматеријали зборуваат за тоа колку всушност се вреднувала македонската чалгиска традиција како културно добро, кажуваат за неуморните теренски истражувања и обработките/анализите на собраните материјали од страна на етномузиколозите, но и од страна на истражувачите од други научни области. Иако чалгијата, денес, веќе не е присутна во истата традиционална форма на изведување, таа сѐ уште одзвучува со освежен звук преку малиот број денешни музички групи, но во речиси комплетно изменет контекст на негување. Интересно е дека никој не останува рамнодушен на оној звук што се негувал од некогашните мајстори на чалгијата и сите денешни и некогашни истражувања биле/се за да се зачува тоа македонско културно богатство и успешно да се пренесе на идните генерации.

\section{ЛИТЕРАТУРА}

\section{Кирилични изданија}

Алушевски, И. Хр. 1980. „Битолската чалгија“. Развийок (месечно списание за литераура, култура и општествени прашања), год. XVIII, бр. 10, 817-823.

Алушевски, И. Хр. 1981. „За некои карактеристики на народните ора од

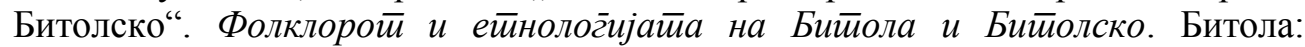
Илинденски денови.

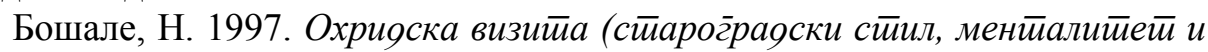
кулитура). Охрид: Радио Охрид.

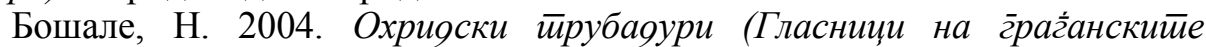
слобояи). Охрид: Летра.

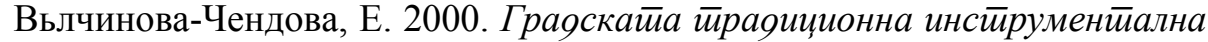

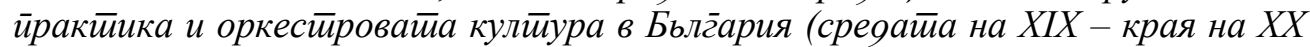
век). София: Рекламно-издателска кьща „Пони“.

Голабовски, С. 1968. „Терминолошки деформации во областа на музичката фолклористика““. Макеgонски фолклор, год. I, бр. 2. Скопје: Институт за фолклор „Марко Цепенков“, 320.

Голабовски, С. 1976. „Некои согледувања за византиски влијанија врз македонската фолклорна мелодика“. Макеgонски фолклор, год. IX, бр. 17. Скопје: Институт за фолклор „Марко Цепенков“, 107-112. 
Голабовски, С. 1989. „За ориенталните влијанија во македонската музика (крајот на XIV до почетокот на XIX век)“. Макеяонски фолклор, год. XXII, бр. 44. Скопје: Институт за фолклор „Марко Цепенков“, 177-183.

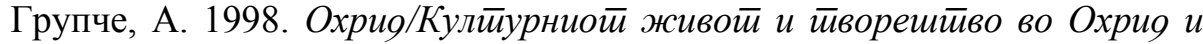
Охрияско во 20. век. Скопје: Матица македонска.

Димов, В. 2005. „Върху някои ориентализми в българската записана музика“. Изкустивовеgски чеиеения. София: Институт за изкуствознание при БАН.

Димов, В. 2007. „Балканските кръчми и кафенета и раждането на локалната записана музика“. Кафене „Евройа“. Ред. Рая Заимова. София: Дамян Яков, 45-59.

Димоски, М. 1976. „Некои податоци за орската традиција на Власите сточари од с. Горна и Долна Белица (Струшко)“. Зборник на трудови од 21. Kongresa Saveza udruženja folklorista Jugoslavije, одржан во Čapljina, 17-21 septembra 1974. Sarajevo, 281-284.

Димоски, М. 1977. „Податоци за орската традиција во Крушево“. Зборник на трудови од XIX конг̄рес на Сојузой на зоруженијайа на фолклористииче на Југ̄ославија, одржан во Крушево, 1972. Пенушлиски, К. и Б. Ристовски (ур). Скопје, 39-42.

Ѓор́́иев, Ѓ. 1977. „Некои особености на влашката вокалноинструментална народна традиција во Крушево“. Зборник на трудови од XIX

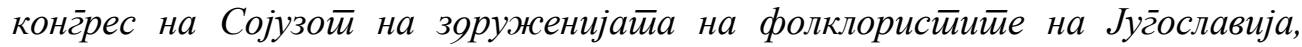
одржан во Крушево, 1972. Пенушлиски, К. и Б. Ристовски (ур). Скопје, 33-37.

Ѓорѓиев, Ѓ. 2009. Охрияскайа йеснойојска йраяииија [партитури за фолклорен ансамбл - прилепски игри, битолски игри, охридски игри]. Скопје: АНПИМ „Танец“.

Жежељ-Каличанин, Т. 2012. Современи зайиси за йраяищијайа во Сйруга и Сйрушко. Скопје: Камелеон.

Жура, В. 1995. Жура за Жура или оо живойойиснийе белешки на Благо Жура $(1916-1985)$. Охрид.

Жура, В. 2009. „Охридската старозаманска песна“. Воведен говор на манифестацијата „Охридски староградски средби“. Охрид.

Жура, В. 2013. „Животот во Охрид во XIX век“. Зборник на трудови од

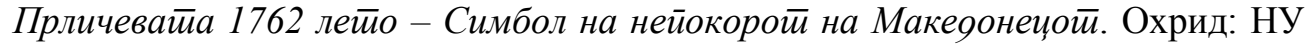
Библиотека „Григор Прличев“ - Охрид.

Златаноски, С. 2009. Песни и ора иееени и свирени оя ансамблой Охрияски йрубаяури [иечатиени музикалии]. Скопје: Сојуз на пронајдувачите и авторите на техничките унапредувања на Македонија.

Јанковић, Љ. С. и Д. С. Јанковић. 1948. Нарояне иг̄ре. IV књига. Београд: Просвета.

Јанковић, Љ. С. и Д. С. Јанковић. 1951. Нарояне иг̄ре. VI књига. Београд: Просвета.

Кауфман, Д. 1990. „От възрожденската чалгия към съвременните сватбарски оркестри“. Бългіарски фолклор, кн. 3, 23-32.

Киселиновић, Ђ. Ј. 1926. Охрияско-йресйанска лира (100 нарояних женских иессама из Охрияа и Пресиее). Битољ: Штампарија Илије Ивановића. 
Китевски, М. 2009. Охрияски нарояни ора [партитури за фолклорен ансамбл - прилепски игри, битолски игри, охридски игри]. Скопје: АНПИМ „Танец“.

Константинов, Хр. Д. 1969. „Еврејско влијание врз една македонска песна“. Макеgонски фолклор, год. II, бр. 3-4. Скопје: Институт за фолклор „Марко Цепенков“", 239-243.

Кузман, А. 2014a. „За некои етномузиколошки аспекти на охридската чалгија“. Макеоонски фолклор, год. XXXVI, бр. 69. Скопје: Институт за фолклор „Марко Цепенков“, 207-216.

Кузман, А. 2014б. „Охридската чалгија - етномузиколошки аспекти“. Зборник на трудови од Музичко-научната манифестација „Струшка музичка

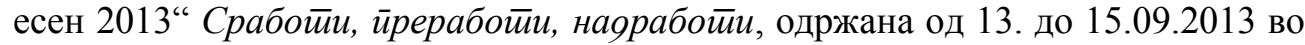
Струга. Скопје: Сојуз на композитори на Македонија - СОКОМ, 109-117.

Кузман, А. 2015а. „Соло инструментална импровизација 'мане' во чалгиската музика“. Зборник на трудови од Меѓународниот симпозиум

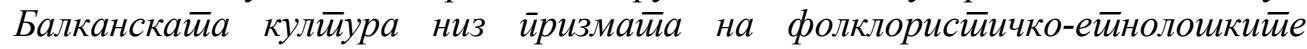
истиражувања, одржан од 19-20.12.2014 во Скопје. Скопје: Институт за фолклор „Марко Цепенков““, 327-333.

Кузман, А. 2015б. „Едукативниот процес при ревитализацијата на чалгиската музика во Р. Македонија, преку примерот на групата 'Chalgia sound system'“. Зборник на трудови од 39. Меѓународна конференција „Струшка музичка есен 2014“" Музика и образование, одржана од 12. до 14.09.2014 во Струга. Скопје: Сојуз на композитори на Македонија - СОКОМ, 87-91.

Кузман, А. 2015в. „Етномузикологот Боривоје Џимревски како инспирација за младите генерации во продолжувањето на музичката фолклорна традиција“. Макеgонски фолклор, год. XXXVII, бр. 70. Скопје: Институт за фолклор „Марко Цепенков“, 9-12.

Кузман, А. 2016а. „За некои од посовремените начини на пренесување на музичката традиција во Р. Македонија“. Макеоонски фолклор, год. XXXVIII, бр. 71. Скопје: Институт за фолклор „Марко Цепенков“, 285-291.

Кузман, А. 2017а. „'Хилјада и седемстотин шестдесет и второ лето’ 'химна' на градот Охрид“. Макеоонски фолклор, год. XXXIX, бр. 72. Скопје: Институт за фолклор „Марко Цепенков“, 185-192.

Кузман, А. 2017б. „Нешто за староградската музика во Република Македонија, низ призмата на чалгиската музичка традиција (од XIX век до денес)“. Зборник на трудови од Меѓународната научна конференција

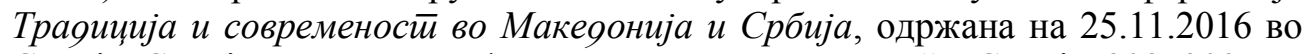
Скопје. Скопје: Институт за фолклор „Марко Цепенков“ - Скопје, 203-209.

Кузман, А. 2017в. „Охрид, Велес, Битола и Скопје како центри на чалгиската музичка култура“. Кониеекст, бр. 15, 155-167.

Кузман, А. 2017г. „Чалгиската музика низ трансформациите од времето“. Сйекйар, год. ХXXV, бр. 70, 157-161.

Кузман, А. 2017д. „Чалгиската традиција како инспирација за истражувањата на етномузикологот Боривоје Џимревски“. Зборник на трудови од Музичко-научната манифестација „Струшка музичка есен 2016“ 
Траяииијайа како инсӣираџија, одржана од 02-04.09.2016 во Струга. Скопје: Сојуз на композитори на Македонија - СОКОМ, 150-153.

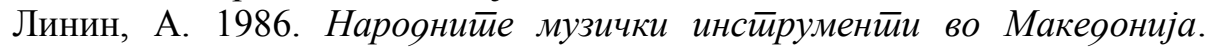
Скопје: Македонска книга.

Маленко, Д. 1977. „Охридската песна и садиловската чалгија“. Билтен произлезен од Манифестацијата Охрияски стиарограяски среяби. Книга 1 и 2. Охрид, 82-101.

Маленко, Д. 1989. Охрияска нарояна иесна и ирриказна. Охрид: Завод за заштита на спомениците на културата и Народен музеј.

Малинов, Т. 2011. „Ало Тончов - бардот на велешката чалгија“ [Магистерски труд]. Скопје: Факултет за музичка уметност.

Минова-Гуркова, Л. (ред). 1999. Така се зборува во Охрия. Скопје: Филолошки факултет „Блаже Конески“, Катедра за македонски јазик и јужнословенски јазици.

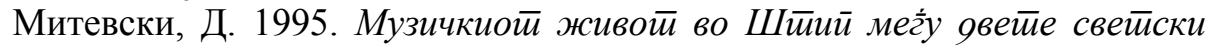
војни. Скопје: НИП „Глобус“.

Опетческа-Татарчевска, И. 1998. „Македонските народни танци од Струга и музиката како нивен составен дел“. [Дипломска работа]. Скопје: Универзитет Св. Кирил и Методиј, ФМУ.

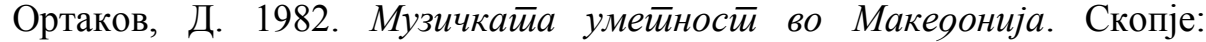
Македонска ревија.

Ортаков, Д. и С. Голабовски. 1978. „Музика“. Охрия и Охрияско низ

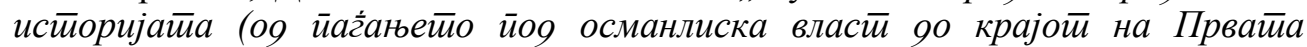
свейска војна). Книга 2. Скопје: Институт за национална историја - Скопје.

Пейчева, Л. 1999. Душайа йлаче - иесен излиза (Ромскийе музиканиии в България и йяхнайа музика). София: ТерАРТ.

Пейчева, Л. и В. Димов. 1999. „’Сладката музика' (Български музиканти за понятието макам)“. Българарски фолклор, книга 3, 51-59.

Пенушлиски, К. 1968. „За поимот народна творба“. Макеоонски фолклор, год. I, бр. 2. Скопје: Институт за фолклор „Марко Цепенков“, 323.

Поленаковиќ, Х. 1976. „За македонската градска песна“. Билтен произлезен од Манифестацијата Охрияски стиарогрраяски среgби. Книга 2. Охрид, 22-34. Култура.

Саздов, Т. 1976. Макеяонскаӣа нарояна ӣоезија (II издание). Скопје:

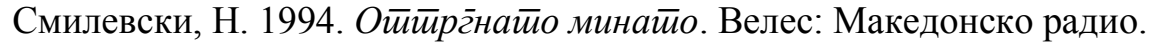

Смилевски, Н. 2014. На Којник яуќан gа имам (Велешки народни песни). Скопје: Гирланда.

Смилески, Д. 1977. „Староградски мотиви во 'Охридско-преспанска лира'“. Билтен произлезен од Манифестацијата Охрияски стиарог̄раяски среgби. Книга 1 и 2. Охрид, 34-42.

Татаровска, Л. 2001. Сйарог̄раяскайа нарояна иеесна во Макеоонија. Скопје: Институт за македонска литература.

Тунтев, В. 2004. „Климе Садило“. Бошале, Н. Охрияски йрубаяури

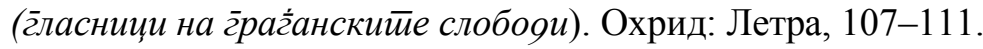


Фирфов, Ж. 1976. „За музичките градски состави и нивните интерпретатори“. Билтен произлезен од Манифестацијата Охрияски стиарограяски среяби. Книга 2. Охрид, 35-41.

Хаџиманов, В. 1968. „Инструменталната играорна музика во Македонија“. Макеоонски фолклор, год. I, бр. 1. Скопје: Институт за фолклор „Марко Цепенков“", 137-146.

Цепенков, М. К. 1980а. Макеоонско нарояно йворешӣво. Книга 2: Нарояни ирриказни - ириказни за живойни/волшебни йриказни. Ред. д-р Кирил Пенушлиски. Скопје: Македонска книга, Институт за фолклор.

Цепенков, М. К. 1980б. Макеоонско нарояно ӣворешӣво. Книга 5: Нарояни ириказни - реалистиччни ириказни. Ред. Д-р Кирил Пенушлиски. Скопје: Македонска книга; Институт за фолклор.

Цепенков, М. К. 1980в. Макеоонско нарояно йворешӣво. Книга 10:

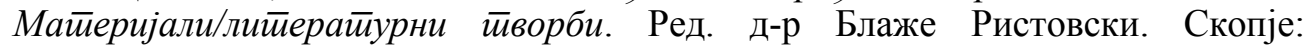
Македонска книга; Институт за фолклор.

Църнушанов, К. 1956. Макеоонски нарояни йесни. София: Българската академия на науките.

Чичаковски, Т. 2012. „Чалгиската традиција во Берово“ [Магистерски труд]. Скопје: ЈНУ Институт за фолклор „Марко Цепенков“.

Џимревски, Б. 1977. „Некои музички карактеристики на влашките свадбени песни од Крушево“. Зборник на трудови од XIX конгрес на Сојузот на здруженијата на фолклористите на Југославија, одржан во Крушево, 1972. Пенушлиски, К. и Б. Ристовски (ур). Скопје, 47-58.

Џимревски, Б. 1983. „Интерпретацијата на македонската градска народна песна од страна на аматерските состави“. Макеgонски фолклор, год. XVI, бр. 32. Скопје: Институт за фолклор „Марко Цепенков“, 145-149.

Џимревски, Б. 1984. „Ориенталните тонски низи во македонската инструментална народна музика“. Макеоонски фолклор, год. XVII, бр. 34. Скопје: Институт за фолклор „Марко Цепенков“, 189-203.

Џимревски, Б. 1985а. Макеоонско нарояно йворешӣво - Орска и

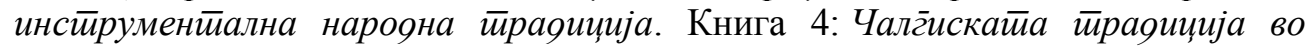
Макеgонија. Скопје: Институт за фолклор „Марко Цепенков“.

Џимревски, Б. 1985б. „Можни аспекти во инструменталната придружба на македонската градска народна песна“. Макеяонски фолклор, год. XVIII, бр. 35. Скопје: Институт за фолклор „Марко Цепенков“, 129-132.

Џимревски, Б. 1986. „Некои методолошки аспекти во истражувањето на народните музички инструменти и инструменталната народна музика“. Макеgонски фолклор, год. ХІХ, бр. 37. Скопје: Институт за фолклор „Марко Цепенков“", 177-181.

Џимревски, Б. 2005. Орска и инстируменитална нарояна тираяиција. Книга 7: Граяска инсӣруменйална музичка йраящиија во Макеgонија [1900 1941]. Скопје: Институт за фолклор „Марко Цепенков““. 


\section{Латинични изданија}

Buchanan, D. 1995. "Metaphors of Power, Metaphors of Truth: The Politics of Music Professionalism in Bulgarian Folk Orchestras". Ethnomusicology, Vol. 39, No. 3, 381-416.

Friedman, V. A. 2011. "Presentations, perceptions and practices of chalgija music in the Republic of Macedonia". Proceedings of the Second Symposium of the International Council for Traditional Music Study Group on Music and Dance in Southeastern Europe How do public presentations affect perceptions and practices of music and dance, regional and national experiences, held in Izmir, Turkey, 7-11 April, 2010. Izmir: ICTM Study Group on Music and Dance in Southeastern Europe, Ege University State Turkish Music Conservatory, 25-35.

Gojković, A. 1989. Narodni muzički instrumenti. Beograd: Vuk Karadžić.

Kuzman, A. 2016b. "Revitalisation of chalgia music in The Republic of Macedonia seen through the prism of the 'Chalgia sound system' band". Proceedings of the International Scientific Conference Popular culture: Reading from below, held in Skopje, 3-4 November, 2014. Skopje: Institute of Macedonian Literature, 658-665.

Kuzman, A. 2016c. "Some aspects of the solo instrumental improvisations in Macedonian Chalgia music". Proceedings of the Fourth Symposium of the ICTM Study Group on Music and Dance in Southeastern Europe Music and dance in Southeastern Europe: New scopes of research and action, held at Petnica Science Center, Republic of Serbia, 24 September - 1 October, 2014. Belgrade: ICTM Study Group on Music and Dance in Southeastern Europe, Faculty of music, University of Arts, 40-45.

Kuzman, A. 2018. "Chalgia music as cultural space and 'meeting point' of different ethnicities". Proceedings of the $5^{\text {th }}$ International Conference "Ohrid Vodici 2017" Runaway world, liquid modernity and reshaping of cultural identities, heritage, economy, tourism and media, held at Ohrid, 17-19 January, 2017. Skopje: Institute for Socio-Cultural Anthropology of Macedonia, University "Euro Balkan”, Skopje, R. of Macedonia, Selçuk Üniversitesi, Konya, Turkey, MIRAS, Social Organization in Support of Studying of Cultural Heritage, Baku, Azerbaijan, 203-207.

O'Connell, J. M. 2005. "In the time of Ala turka: Identifying Difference in Musical Discourse.” Ethnomusicology, Vol. 49, No. 2, 177-205.

Opetcheska-Tatarchevska, I. 2006. "Macedonian traditional urban dance model (its openings toward the west musical culture)". Papers of the International Symposium in Tirana Urban Music in the Balkans: drop-out ethnic identities or a historical case of tolerance and global thinking?, held on September 28 - October 01, 2006. Sokol Shupo (ed.). Tirana: Asmus, 435-444.

Pennanen, R. P. 2004. "The Nationalization of Ottoman Popular Music in Greece”. Ethnomusicology, Vol. 48, No. 1, 1-25.

Pennanen, R. P. 2008. "Lost in scales: Balkan Folk Music Research and the Ottoman Legacy". Muzikologija, 2 [8], 127-147.

Rice, T. 1982. "The Surla and Tapan Tradition in Yugoslav Macedonia". The Galpin Society Journal, Vol. 35, 122-137. 
Rice, T. 2002. "Bulgaria or Chalgaria: The Attenuation of Bulgarian Nationalism in a Mass-Mediated Popular Music". Yearbook for Traditional Music, Vol. 34, 25-46.

Seeman, S. T. 1990. "Continuity and Transformation in the Macedonian Genre of Čalgija: Past Perfect and Present Imperfective” [Master's Thesis paper]. Seattle: University of Washington.

Seeman, S. T. 2012. "Macedonian Čalgija: A Musical Refashioning of National Identity". Ethnomusicology forum, 21/3, 295-326.

\section{Сајтографија}

„Chudila se mila mama komu da me davat - Ohridski trubaduri“ https://www.youtube.com/watch?v=M5jW9B_wMn8 [Пристапено на 05.11.2020].

„Koce berberot čalgadjijata - Jonče Hristovski“
https://www.youtube.com/watch?v=JJVJpYO2NS4 [Пристапено на 26.03.2020].

„Битола во 1950 година“ (Ова го пишува под видеото, бидејќи аудиоснимката од песната е врз видеоснимката преземена од архивата на MTВ, но станува збор за „Ако одам во Битола“) https://www.youtube.com/watch?v=Az9Ox9w6EHg [Пристапено на 04.09.2018].

„Распеани

Беровчани“"

https://www.youtube.com/watch?v=IgKNmELkAXw\&list=PLQcunzPHnlZ 8Rn0z JCP6aFSMZ2U5tK9R [Пристапено на 08.09.2021]
,Jonče
Hristovski
Svirete
$\mathrm{mi}$
čalgii“،

https://www.youtube.com/watch?v=34Qf-wkfV2k [Пристапено на 04.09.2018].

„Bioritam - Sadilo“ https://www.youtube.com/watch?v=VDpn8t281Rk

[Пристапено на 26.09.2018].

„Климе Садило со тајфата чалгаџии. 'Охридски трубадури““ https://www.youtube.com/watch?v=MBmk7mMB3Sc [Пристапено на 27.03.2020].

„Охридските Трубадури и Ор. Климе Садило“ https://www.youtube.com/watch?v=sUEZBsbj_8o [Пристапено на 27.03.2020].
,Ohridski
trubaduri
Stojan
Zlatanoski“"

https://www.youtube.com/watch?v= gBej2YYMJY [Пристапено на 27.03.2020].

„Печат 25.02.2015“ (документарна емисија на телевизија ТВМ),

Интервју со Милка Садило (керка на Климе Садило) https://www.youtube.com/watch?v=zeRhK3cwe3g\&t=66s [Пристапено на 27.03.2020].

„Историја на македонската народна музика еп. 1.“ https://www.youtube.com/watch?v=7LsTH5BSa4w [Пристапено на 27.03.2020].

$$
\text { „Со љубов на Велес - }
$$

велешани“ https://www.youtube.com/watch?v=M2O1T5ZTf I;

https://www.youtube.com/watch?v=QZq3uPTJD4A [Пристапено на 27.03.2020].

$$
\text { „Raspeani gradovi - } \quad \text { Veles mtvretro.blogspot.com“ }
$$

https://www.youtube.com/watch?v=H3V01SRSkuc [Пристапено на 27.03.2020].

$$
\text { „Садило, тајфите и }
$$

https://www.youtube.com/watch?v=65aqxIdMjuc [Пристапено на 07.09.2021]. 
Aleksandra Kuzman

\title{
MACEDONIAN CHALGIA THROUGH THE RESEARCHES, SONGS, FOLK STORIES AND DOCUMENTARIES
}

\begin{abstract}
Summary
The Macedonian chalgia as a very specific musical genre nurtured in the cities mostly in the XIX and XX centuries, after its silent and slow disappearing from the Macedonian musical tradition and culture, left an imprint in the historical documents, songs, stories, documentaries etc. Besides a few old and new songs where the term "chalgia" is mentioned, there are documentaries which are dedicated to this topic as a result of an affirmation of the old-urban song and chalgia tradition.

This old-urban musical tradition has always been an inspiration for the researchers and scholars that tried to preserve and save this intangible cultural heritage. The most important materials, where we can find evidence that chalgia existed in the past, are collected from the most known gatherer of the Macedonian folklore - Marko Cepenkov. Those materials consist of descriptions of the chalgia instruments, as well as folk stories where the term "chalgia" is mentioned.
\end{abstract}


